\title{
Cross-linked coacervates of cashew gum and gelatin in the encapsulation of pequi oil
}

\author{
Joana de Barros Alexandre ${ }^{1}$ Tiago Linhares Cruz Tabosa Barroso ${ }^{2}$ Marília de Albuquerque Oliveira $^{3}$ \\ Francisco Rogênio da Silva Mendes ${ }^{4}$ José Maria Correia da Costa ${ }^{2}$ \\ Renato de Azevedo Moreira ${ }^{5}$ Roselayne Ferro Furtado $^{3 *}$ iD
}

${ }^{1}$ Programa de Pós-graduação em Ciências Naturais, Universidade Estadual do Ceará (UECE), Fortaleza, CE, Brasil. ${ }^{2}$ Curso de graduação em Engenharia de Alimentos, Universidade Federal de Ceará (UFC), Fortaleza, CE, Brasil.

${ }^{3}$ Embrapa Agroindústria Tropical, 60511110, Fortaleza, CE, Brasil. E-mail: roselayne.furtado@embrapa.br. "Corresponding author. ${ }^{4}$ Programa de Pós-graduação da Rede Nordeste de Biotecnologia (RENORBIO), Fortaleza, CE, Brasil. ${ }^{5}$ Universidade de Fortaleza (UNIFOR), Fortaleza, CE, Brasil.

\begin{abstract}
Pequi oil is rich in bioactive compounds which can be encapsulated to increase protection against extrinsic environmental factors. A delayed degradation of pequi oil may occur by using microencapsulation technology, in addition to masking unpleasant flavors and aromas. Complex coacervation is a technique based on the electrostatic interaction between two oppositely charged biopolymers which form a matrix complexed around an agent of interest. However, cross-linking the particles is often necessary in order to make them more rigid. The objective of this research was to produce and characterize pequi oil microparticles in a cashew gum (CG) and gelatin (GE) matrix cross-linked with tannic acid. Cross-linked pequi oil microparticles were produced by varying the concentrations of biopolymers (0.5\% to $1.5 \%$ ) and tannic acid $(0.3 \%$ to $8.1 \%)$ using a rotational central compound design. Ratio of cashew gum, gelatin and oil was $2: 1: 1$ ( $\mathrm{m} / \mathrm{m} / \mathrm{m}) ;$ respectively, at pH 4.5. The cross-linking process was performed with tannic acid for 30 minutes at $40{ }^{\circ} \mathrm{C}$. The optimized formulation by means of the rotational central compound design for microparticle formation was $0.65 \%$ biopolymers (CG and GE) and $6.9 \%$ tannic acid. Increasing the tannic acid percentage in the cross-linking of the pequi oil particles had a higher yield and encapsulation efficiency. Cross-linking provided an increase in the degradation temperature of material; and consequently, improved the thermal stability of the particles. The cross-linking process was advantageous in producing the microparticles.
\end{abstract}

Key words: microencapsulation, complex coacervation, cross-linking, tannic acid, encapsulation efficiency.

Coacervados reticulados de goma de cajueiro e gelatina no encapsulamento de óleo de pequi

RESUMO: O óleo de pequi é rico em compostos bioativos, os quais podem ser encapsulados para aumentar a proteção a fatores extrínsecos. A tecnologia de microencapsulamento, além de retardar a degradação do composto ativo, possibilita mascarar aromas e sabores indesejáveis. A coacervação complexa é uma técnica baseada na interação eletrostática entre dois biopolímeros com cargas opostas, que formam uma matriz complexada ao redor do agente de interesse. Entretanto, muitas vezes, se faz necessário o uso da reticulação para tornar as partículas mais rígidas. O objetivo deste trabalho foi produzir e caracterizar micropartículas de óleo de pequi em matriz de goma de cajueiro (GC) e gelatina (GE) reticulada com ácido tânico. As micropartículas de óleo de pequi reticuladas foram produzidas variando as concentrações de biopolímeros $(0,5 \%$ a $1,5 \% \mathrm{~m} / \mathrm{v})$ e do ácido tânico, em relação à massa de biopolímeros $(0,3 \%$ a $8,1 \% \mathrm{~m} / \mathrm{m})$, a partir de um delineamento de composto central rotacional. A proporção de GC, GE e óleo foi de 2:1:1 (m/m/m), respectivamente, em pH 4,5. O processo de reticulação foi realizado com ácido tânico por 30 minutos a $40{ }^{\circ} \mathrm{C}$. A formulação otimizada foi de $0,65 \%$ ( $\mathrm{m} / \mathrm{v}$ ) de biopolímeros $(\mathrm{GC}$ e $\mathrm{GE})$ e $6,9 \%$ (m/m) de ácido tânico. $O$ aumento do percentual de ácido tânico na reticulação das partículas de óleo de pequi conferiu maior rendimento e eficiência de encapsulamento. A reticulação proporcionou aumento na temperatura de degradação do material, e consequente estabilidade térmica das partículas. O processo de reticulação foi vantajoso para a produção das micropartículas.

Palavras-chave: microencapsulamento, coacervação complexa, reticulação química, acidotânico, eficiência de encapsulamento.

\section{INTRODUCTION}

Pequi is found in Northeast Brazil (Caryocar coriaceum Wittm.) and predominantly in the Midwest region of Brazil (Caryocar brasiliensis
Camb.), and it has significant importance in traditional local cuisine. Oil from pulp or the almond has a high omega 9 content and represents a source of important antioxidants (carotenoids, phenolic compounds, vitamins A and E) (FIGUEIREDO et al., 
2016; MAGALHÃES et al., 2018). It has been used in treating scarring, as well as gastric, inflammatory and respiratory diseases, including coughing and asthma (QUIRINO et al., 2009; OLIVEIRA et al., 2010).

Bioactive compounds present in pequi oil are considered to have low stability and can be degraded and cause color changes and loss of biological activity (PINTO et al., 2018). A way to protect pequi oil bioactive compounds to increase kinetic stability and functional activity would be to apply the microencapsulation method. This method has the objective to protect the oil from extrinsic factors and undesirable chemical reactions, as well as to mask its strong aroma and taste that may not be desirable in some products. Microparticle formation can be accomplished by various processes, including coacervation. This process is highlighted in encapsulating hydrophobic compounds because in addition to being one of the simplest techniques, it is also based on the phase separation of an oil-inwater emulsion without the use of organic solvents (ROY et al., 2018). The complex coacervation process involves the interaction between two or more opposite charge polymers in aqueous solution. Interaction occurs under specific conditions of $\mathrm{pH}$, temperature and ionic strength (COMUNIAN et al., 2016; GOMEZ-ESTACA et al., 2016; TIMILSENA et al., 2016; ROY et al., 2018).

Studies showed that many combinations of wall materials are used in complex coacervation, with coacervates formed from gum arabic (GA)/ gelatin (GE) being one of the most common and effective (SHADDEL et al., 2018; MA et al., 2019). However, GA has a high import cost, which makes it attractive to use other gums, especially regional ones such as cashew gum (CG). CG is an exudate from the Anacardium occidentale tree, very common in the northeast region, and has similar characteristics to those of gumarabic; although, it has a lower viscosity. In turn, GE is a hydrocolloid obtained from the bones and skins of mammals and fish, which has cationic properties at $\mathrm{pH}$ below the isoelectric point $(\mathrm{pH}$ 4.7 and 5.6) and anionic characteristics above the isoelectric point (COMUNIAN et al. al., 2016).

Despite the simplicity, low cost and encapsulation efficiency of applying the complex coacervation method, it has some disadvantages such as the fragility of the resulting particles under certain conditions of $\mathrm{pH}$, temperature and ionic strength. These particles have been subjected to the chemical cross-linking process in order to improve these characteristics (COMUNIAN et al., 2016; COMUNIAN et al., 2017; TIMILSENA et al., 2017).
The cross-linking process consists of using crosslinking agents aiming to form polymer networks or a lattice. This technique can occur through chemical processes which join the polymer chains by chemical bonds; physical processes through the use of complexing agents; and radioactive methods. Chemical cross-linking aims to increase strength, modify certain properties of a polymer, increase its chemical and thermal stability, structural stiffness, permeability and color; in other words to transform the functional and structural properties of the polymer to find specific material applications (ANVARI \& CHUNG, 2016).

Tannic acid belongs to the group of tannins and contains abundant hydroxyl groups in its structure, allowing its use as a cross-linker (SANTOS et al. 2018; MUHOSA et al. 2019), especially of protein molecules such as gelatin. Cross-linking occurs due to the formation of hydrogen bonds between gelatin carbonyl groups and tannic acid hydroxyl groups (HU et al., 2016).

In view of the above, this study aimed to produce, cross-link and characterize pequi oil microparticles in a CG and GE matrix, using tannic acid as a cross-linker employing a rotational central compound design. The optimized formulation of a cross-linking agent and biopolymer was determined by evaluating the encapsulation efficiency, carrying capacity and yield. The best condition was used to physically and chemically characterize the microparticles.

\section{MATERIALS AND METHODS}

Cashew gum was collected from cashew plants in the Pacajus Experimental Field, belonging to Embrapa Tropical Agroindustry (Fortaleza, Brazil). 225H type B gelatin was purchased from Rousselout ${ }^{\circledR}$. Pequi oil (Caryocar coriaceum Wittm.) was purchased from producers in Barbalha-CE. All reagents used were of analytical grade. Hydrochloric acid - $\mathrm{HCl}(2 \mathrm{M})$ and sodium hydroxide - $\mathrm{NaOH}(2 \mathrm{M})$ were used to control the $\mathrm{pH}$ of the solutions.

\section{Isolation and characterization of cashew gum}

The isolation of polysaccharides from cashew exudate followed the methodology described by TORQUATO et al. (2004) with modifications. The exudate was ground and solubilized in water in the proportion of $300 \mathrm{~g}$ of the sample to one liter of water. After solubilization, the sample was filtered and centrifuged $(15,303 \mathrm{x} \mathrm{g})$ for $10 \mathrm{~min}$ at $25^{\circ} \mathrm{C}$. Then the sample was precipitated in ethanol $(1: 3$ 
sample/ethanol) for $24 \mathrm{~h}$ at $4{ }^{\circ} \mathrm{C}$. Excess ethanol was discarded and the precipitate was dried in an air circulation oven at $60{ }^{\circ} \mathrm{C}$. Finally, the dried material was ground, resulting in isolated cashew gum.

\section{Formation of microparticles with pequi oil}

The coacervates were prepared from a final $600 \mathrm{~mL}$ solution according to the procedure described by NASCIMENTO et al. (2016) using a ratio of 2:1:1 (m/m/m) (CG:GE:pequi oil) for treatments. The amount of biopolymer and cross-linker was determined by experimental design (Table 1).

An emulsion of $200 \mathrm{~mL}$ volume was initially prepared. Next, $400 \mathrm{~mL}$ of distilled water was added. The two steps were followed by ultra turrax homogenization (IKA ${ }^{\circledR}$ T25) at $10,000 \mathrm{rpm}$ for 15 minutes. Finally, the $\mathrm{pH}$ of the mixture was adjusted with $\mathrm{HCl}(2 \mathrm{M})$ and $\mathrm{NaOH}(2 \mathrm{M})$ to 4.5 and the solution was kept at $4{ }^{\circ} \mathrm{C}$ overnight. After coacervate formation, the material was centrifuged at $10,000 \mathrm{rpm}$ for 10 minutes at $25^{\circ} \mathrm{C}$. The precipitate was collected for the chemical cross-linking process.

In this study, the influence of two independent variables was evaluated: biopolymers $\%$ - BP (CG/GE) and tannic acid \% - TA (cross-linker) using a rotational central compound design (RCCD), as described in table 1 .

The experimental design was performed using Statistica ${ }^{\mathrm{TM}} 10$ software based on four factorial points, four axial points, and three central points, totaling eleven assays for the microparticle formation. The dependent variables evaluated were: total oil, surface oil, encapsulation efficiency, carrying capacity, solubility, drying yield and swelling degree.

\section{Tannic acid cross-linking}

Tannic acid percentage was calculated regarding the mass of the biopolymers and added to the coacervate solution under stirring at $40{ }^{\circ} \mathrm{C}$ for 30 minutes. The material was centrifuged three times with distilled water at $4000 \mathrm{rpm}$ for 3 minutes. The precipitate was collected, frozen in an ultra-freezer for $24 \mathrm{~h}$; and subsequently, lyophilized (Liotop LP 820).

\section{Encapsulation efficiency (EE)}

The EE was determined by relating the total, surface and initial oil content according to equation 1 :

$$
E E(\%)=\frac{(\text { Total Oil-Surface Oil) }}{\text { InitialOil }} \times 100 \text { Equation } 1
$$

\section{Total oil determination}

The methodology for determining total oil was adapted from WANG et al. (2014). The freezedried cross-linked microparticles were dispersed in a $4 \mathrm{~N} \mathrm{HCl}$ solution at a ratio of $1: 30(\mathrm{~g} / \mathrm{mL})$ and agitated in a Shaker (SOLAB SL 222) for $60 \mathrm{sec}$. Then half the volume of the $\mathrm{HCl}$ solution was added with hexane and stirred for $24 \mathrm{~h}$ at room temperature. The solution was centrifuged at $11,000 \mathrm{rpm}$ at $20{ }^{\circ} \mathrm{C}$ for $45 \mathrm{~min}$. The organic phase was separated and placed for volatilization for $12 \mathrm{~h}$ in a circulating oven (SOLAB SL 102) at $70{ }^{\circ} \mathrm{C}$. The total oil was determined by gravimetry after evaporation of the solvent, and its percentage calculated according to equation 2 .

$$
T O(\%)=\frac{E O \times 100}{I O} \quad \text { Equation } 2
$$

In which: TO is the total oil percentage, EO is the amount of encapsulated oil and IO is the initial amount of oil.

Table 1 - Coded values and uncoded values (real experimental values) of the independent variables (biopolymers- BP and tannic acid-

\begin{tabular}{|c|c|c|c|c|c|c|}
\hline \multirow[t]{2}{*}{ Assays } & \multicolumn{2}{|c|}{------Coded values------- } & \multicolumn{2}{|c|}{----------------Uncoded values--------------- } & \multicolumn{2}{|c|}{--------------Quantity (g)------------- } \\
\hline & $\% \mathrm{BP}$ & $\% \mathrm{TA}$ & $\% \mathrm{BP}$ & $\% \mathrm{TA}$ & $\mathrm{BP}$ & TA \\
\hline 1 & -1 & -1 & 0.65 & 1.42 & 3.90 & 0.05 \\
\hline 2 & +1 & -1 & 1.35 & 1.42 & 8.10 & 0.11 \\
\hline 3 & -1 & +1 & 0.65 & 6.88 & 3.90 & 0.27 \\
\hline 4 & +1 & +1 & 1.35 & 6.88 & 8.10 & 0.56 \\
\hline 5 & -1.41 & 0 & 0.50 & 4.15 & 3.00 & 0.12 \\
\hline 6 & +1.41 & 0 & 1.50 & 4.15 & 9.00 & 0.37 \\
\hline 7 & 0 & -1.41 & 1.00 & 0.30 & 6.00 & 0.02 \\
\hline 8 & 0 & +1.41 & 1.00 & 8.00 & 6.00 & 0.48 \\
\hline 9 & 0 & 0 & 1.00 & 4.15 & 6.00 & 0.25 \\
\hline 10 & 0 & 0 & 1.00 & 4.15 & 6.00 & 0.25 \\
\hline 11 & 0 & 0 & 1.00 & 4.15 & 6.00 & 0.25 \\
\hline
\end{tabular}
TA percentage) according to the rotational central compound design (RCCD).

Ciência Rural, v.49, n.12, 2019. 


\section{Surface oil determination}

A methodology adapted from COMUNIAN et al. (2016) was implemented for determining surface oil. The precipitated and dried material was transferred to a flask and added with water and hexane at a ratio of $2: 1$, respectively $(\mathrm{mL} / \mathrm{mL})$. The mixture was stirred for 3 minutes. The solution was centrifuged at 10,000 rpm for 10 minutes at $25^{\circ} \mathrm{C}$. The organic phase was left in an air circulation oven at $70{ }^{\circ} \mathrm{C}$ for $3 \mathrm{~h}$. The amount of surface oil was determined by gravimetry and its percentage calculated according to equation 3 .

$$
S O(\%)=\frac{N E O X 100}{I O} \quad \text { Equation } 3
$$

In which: SO is the surface oil percentage, NEO is the amount of oil that has not been encapsulated, and IO is the amount of initial oil.

\section{Loading Capacity (LC)}

The LC was determined considering the oil retained by the carrier particle mass (equation 4).

$$
\text { LC }(\%)=\frac{\text { Totaloil }}{\text { Finalmass }} \times 100
$$

Equation 4

\section{Solubility}

Solubility was determined as described by CANO-CHAUCA et al. (2005) with modifications. A solution of $0.25 \mathrm{~g}$ of microparticles in $25 \mathrm{~mL}$ of distilled water was prepared. The solution was stirred for one minute on a magnetic stirrer and centrifuged (4276.4 $\mathrm{x} \mathrm{g}$ for $5 \mathrm{~min}$ at $25^{\circ} \mathrm{C}$ ). Next, $15 \mathrm{~mL}$ aliquot of the supernatant was placed in a previously weighed petri dish and dried in a circulating air oven at $105^{\circ} \mathrm{C}$ for $5 \mathrm{~h}$. Solubility was calculated by the mass difference expressed as a percentage of solubility.

\section{Microparticle yield}

Microparticle yield after cross-linking and drying was performed according to the methodology of HUANG et al. (2012), and the percentage was calculated from equation 5 :

$$
Y=\frac{M f}{M 0} \times 100 \quad \text { Equation } 5
$$

In which: $\mathrm{Y}$ is the percentage yield, $\mathrm{M}_{\mathrm{f}}$ is the value in grams of final dry mass and $M_{0}$ is the value in grams of the initial mass (gum mass + gelatin mass + oil mass).

\section{Swelling degree}

The swelling degree of the cross-linked and dried microparticles was determined according to the methodology proposed by XU et al. (2003). The total mass of the initial sample $\left(\mathrm{M}_{0}\right)$ was quantified in a Gooch filter and this was immersed in distilled water for $24 \mathrm{~h}$. Excess water was removed and the final wet mass $\left(\mathrm{M}_{\mathrm{f}}\right)$ was determined. The degree of swelling was calculated as a function of the initial mass of the sample, according to Equation 6.

$S D=\frac{M f-M o}{M f}$

Equation 6

\section{Statistical analysis}

All tests were performed in triplicate and submitted to analysis of variance (ANOVA) at 5\% significance level $(\mathrm{P}<0.05)$ using Statistica ${ }^{\mathrm{TM}} 10$ software.

\section{Microparticle characterization}

The optimized condition was submitted to the following analyzes:

\section{Scanning electron microscopy}

Microparticle morphology was examined under a scanning electron microscope (Zeiss, DSM940A). Samples were metalized with a thin gold layer produced by an evaporator (Emitech, k 550).

\section{Thermogravimetric analysis (TGA)}

Thermogravimetric analysis (TGA) of non-cross-linked and cross-linked microparticles was performed on an STA 6000 device (Perkin Elmer). For this procedure, $10 \mathrm{mg}$ of the samples were heated under nitrogen atmosphere at a rate of $10^{\circ} \mathrm{C} / \mathrm{min}$, with a temperature variation of $25^{\circ} \mathrm{C}$ to $600{ }^{\circ} \mathrm{C}$, and a gas flow rate of $20 \mathrm{~mL} / \mathrm{min}$.

\section{Infrared spectroscopic analysis}

The cross-linked and non-cross-linked microparticle samples were analyzed by Fourier transform infrared spectroscopy using an attenuated total reflectance sensor on a spectrometer (FTLA 2000-102, ABB- BOMEN, USA). Scanning was performed at a wavelength range of $400-4000 \mathrm{~cm}^{-1}$ and a resolution of $4 \mathrm{~cm}^{-1}$.

\section{Acute microparticle toxicity test}

The toxicity study of tannic acid crosslinked and non-cross-linked CG/GE microparticles was evaluated in female Wistar rats weighing between $120 \mathrm{~g}$ and $180 \mathrm{~g}$ and ages between 8 and 12 weeks. Animals were acquired by the Experimental Biology Center - NUBEX of the University of Fortaleza (UNIFOR) and kept at room temperature, receiving food and water. The entire procedure followed the rules issued by the National Council for Animal Experimentation (CONCEA), and was also approved by the Ethics Committee of the University of Fortaleza through Protocol No. 3405260218. 
Rats were weighed and separated into four groups of five animals, one of which was the control group. The microparticles were dispersed in distilled water to obtain the final concentration of $5 \mathrm{mg} / \mathrm{kg}$ concerning actual weight per animal. Aliquots of the dispersions were administered to the animals orally and the control group received only filtered water. Animals were observed for fifteen days for reflexes, hair loss and behavior in response to touch and irritability. They were made available to the Center of the University of Fortaleza after the procedure.

\section{RESULTS AND DISCUSSION}

Encapsulation efficiency (EE) and loading capacity (LC) $\mathrm{EE}$ and LC are two important factors to evaluate the efficiency of the encapsulation process. High EE indicates that a significant amount of the active compound is reported within the microparticles rather than its surface, as well as having a suitable LC which indicated that the particle mass contains a high amount of the encapsulated core compound. Thus, particles with low LC may not be viable since a larger amount of encapsulated material would be required (SHADDEL et al., 2018). The LC above $50 \%$ is also undesirable as it decreases the protection of the matrix over the core (SHADDEL et al., 2018). The microparticles showed surface and total oil content ranging from $0.46 \%$ to $4.45 \%$ and from $3.54 \%$ to $71.85 \%$, respectively. The EE ranged from $2.60 \%$ to $70.98 \%$, and LC ranged from $8.3 \%$ to $42.99 \%$ (Table 2 ).

The experimental design evaluation did not indicate a significant difference for surface oil content $(\mathrm{P}>0.05)$. In turn, there was a significant difference of total oil content for the linear effects of biopolymer concentration (X1) and tannic acid percentage (X2), as well as the interaction between these two variables (Figure 1). Thus, it was possible to establish a mathematical model for the total oil content $(\mathrm{Y})\left(\mathrm{R}^{2}=98 \%\right)$ (equation 7$)$ :

$\mathrm{Y}=17.85$ - 13.54.X1 + 16.05X2 - 13.79.X1.X2

Equation 7

The highest EE and $\mathrm{LC}$ was reported in treatment 3 with $0.65 \% \mathrm{BP}(\mathrm{GC} / \mathrm{GE})$ and $6.9 \%$ TA. These parameters showed significant differences at $5 \%$ significance. According to figure 1 , it is observed that the best results are reported in the region where there is a higher percentage of cross-linkers. COMUNIAN et al. (2018); ZHANG et al. (2011) reported that the use of cross-linking agents (synapic acid and tannic acid, respectively) also increased the EE of gelatin and polysaccharide microparticles. Results reported in this research indicated that the incorporation of tannic acid caused a change in the matrix of the coacervates, possibly due to an increase in rigidity in the polymeric matrix, reducing the amount of surface oil and concentrating pequi oil inside the particles. According to equation 1, more oil inside the particles results in higher EE.

\section{Solubility and degree of swelling}

Solubility is the maximum amount of a solute that can be dissolved in a certain amount of solvent at a specific temperature. Depending on the application of the microparticles and the nature of the wall material, the cross-linking process is advantageous as it provides a higher stiffness of the matrix and may allow gradual release of the

Table 2 - Evaluated parameters of microparticles according to the rotational central compound design (RCCD).

\begin{tabular}{lcccccc}
\hline Assays & TO(\%) & SO(\%) & EE (\%) & LC(\%) & Solubility & Yield \\
\hline 1 & $10.23 \pm 6.84$ & $4.05 \pm 4.68$ & 8.84 & 11.63 & $2.66 \pm 0.08$ & $21.76 \pm 0.16$ \\
2 & $5.28 \pm 5.53$ & $2.65 \pm 4.46$ & 5.11 & 8.30 & $2.94 \pm 0.65$ & $15.73 \pm 0.47$ \\
3 & $71.85 \pm 2.99$ & $4.45 \pm 6.21$ & 70.98 & 42.99 & $1.16 \pm 0.23$ & $39.77 \pm 0.03$ \\
4 & $11.74 \pm 7.83$ & $3.30 \pm 6.21$ & 11.43 & 13.14 & $2.36 \pm 0.45$ & $21.24 \pm 1.55$ \\
\hline 5 & $34.36 \pm 1.70$ & $1.56 \pm 0.69$ & 33.09 & 21.5 & $1.86 \pm 0.08$ & $38.77 \pm 0.25$ \\
\hline 7 & $3.77 \pm 1.25$ & $0.46 \pm 0.28$ & 2.60 & 8.91 & $4.82 \pm 0.08$ & $7.89 \pm 0.29$ \\
\hline 8 & $3.54 \pm 1.13$ & $0.84 \pm 0.28$ & 3.46 & 13.56 & $1.08 \pm 0.17$ & $7.77 \pm 3.35$ \\
11 & $46.21 \pm 6.92$ & $3.40 \pm 4.88$ & 45.63 & 33.97 & $4.14 \pm 0.76$ & $32.08 \pm 2.33$ \\
\hline
\end{tabular}

*TO: Total oil; SO: Superficial oil; EE: Encapsulation efficiency; LC: Loading capacity. 


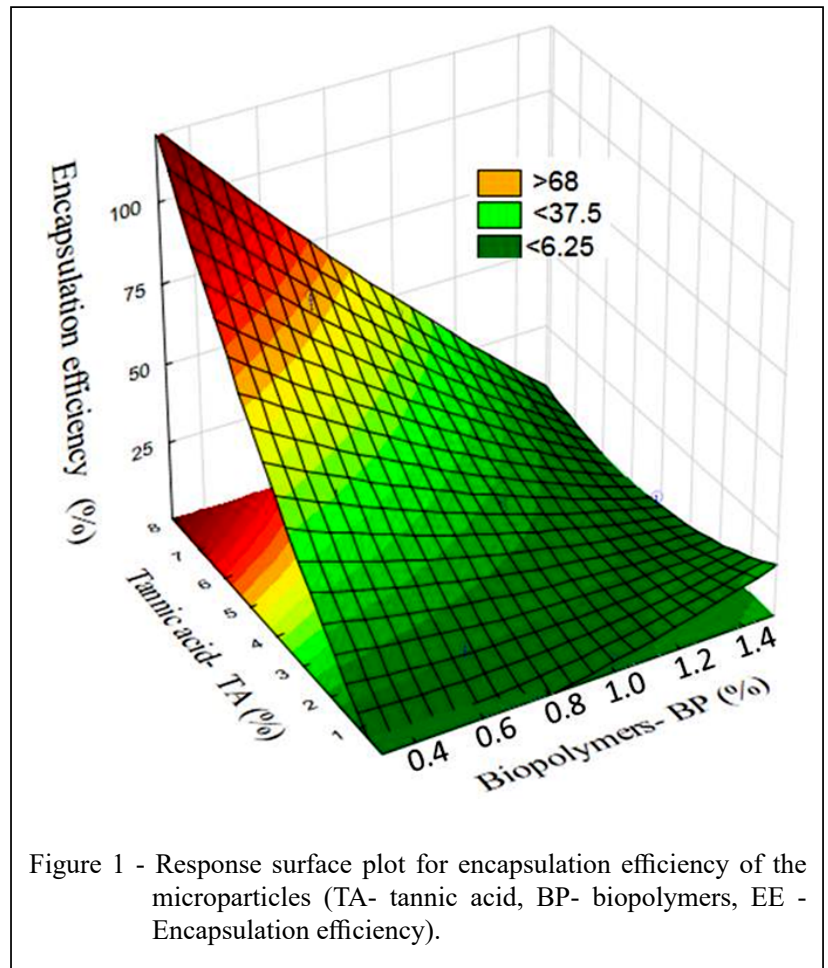

encapsulated material. The microparticles had low solubility, ranging from $1.08 \%$ to $4.82 \%$, and no significant difference was reported between the treatments $(\mathrm{P}>0.05)$.

The low water solubility of the particles can be explained by the reduction of the free $\mathrm{OH}$ groups of GC and GE after cross-linking (figure 5). Similar results were reported by MENEZES et al. (2019) when evaluating the effect of tannic acid as a cross-linker in fish skin gelatin.

The swelling degree was evaluated according to the expansive capacity of the cross-linked microparticles when absorbing water. In figure 2 it was reported that the swelling ranged from $80 \%$ to $94 \%$, with the lowest values related to the treatments with the highest tannic acid concentration. In addition to intermolecular cross-linking which usually involves polymer expansion in an aqueous medium, internal cross-linking and greater matrix rigidity may have occurred (GEBBEN et al. 1985). Increased stiffness of the microparticle matrix makes water absorption difficult, and a decrease in swelling and solubility may consequently occur. RIBEIRO et al. (2015) reported the same behavior (higher degree of cross-linking results in lower swelling capacity) in gum particles cross-linked with sodium trimetaphosphate. PRATA et al. (2008) also observed a decrease in the swelling capacity of cross-linked glutaraldehyde particles compared to non-cross-linked particles.

Yield

The yield of cross-linked and dehydrated microparticles ranged from $7.77 \%$ to $39.77 \%$, with the highest value referring to the conditions with the highest tannic acid percentage. These results showed a significant difference at a 5\% level. Treatment $3(0.65 \%$ BP and 6.9\% TA) showed the best yield, indicating the formation of more consistent coacervates with the increase in tannic acid concentration. Material losses were reported in the centrifugations performed with distilled water to eliminate free tannic acid. Another form to eliminate the residual cross-linking agent could improve this technological aspect. SILVA et al. (2017) reported similar results of about $40 \%$ by encapsulating pequi oil by complex coacervation using a cashew and chitosan gum matrix. SIOW et al. (2013) achieved yields ranging from 65 to $85 \%$ using GA and GE in the garlic oil encapsulation.

\section{Characterization of cross-linked coacervates}

According to the performed analyzes, treatment $3(0.65 \%$ BP and $6.9 \%$ TA) showed very promising results, especially regarding the yield and 


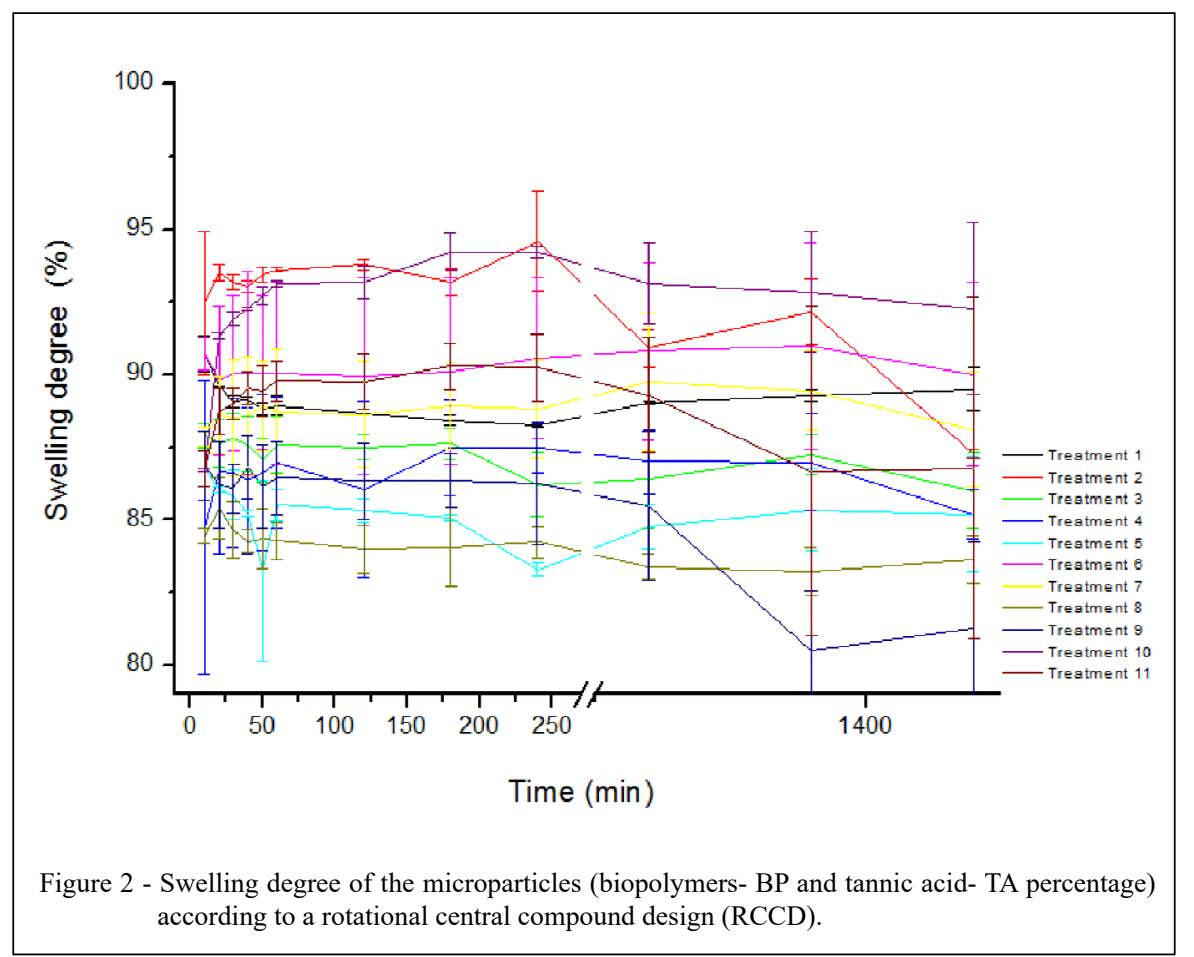

EE of pequi oil. In order to characterize the external structure of these cross-linked particles compared to non-cross-linked particles, experiments were only performed on coacervates without the core material in the optimized BP and TA condition.

\section{Scanning electron microscopy}

Scanning electron microscopy (SEM) was used to evaluate the structure and appearance of cross-linked and non-cross-linked microparticles. The lyophilization drying process agglomerates the particles and bridge-like structures are observed. Other researches in the literature have also observed these characteristics in cross-linked and lyophilized particles (ROCHA-SELMI et al., 2013; COMUNIAN et al., 2018). In the figures for the non-cross-linked microparticles ( $3 a$ and $3 b$ ), it is possible to verify a smoother and more homogeneous structure when compared to the cross-linked micro-particles (3c and 3d). COMMUNIAN et al. (2018) reported controversial characteristics in the morphology of polysaccharide and gelatin particles, depending on the cross-linking agent used.

\section{Thermogravimetric analysis (TGA)}

Figure 4 shows the differential thermogravimetric curves (DTG) for non-cross- linked (Figure 4a) and cross-linked (Figure 4b) microparticle samples. According to the figure, we can observe that there was a degradation event at a temperature close to $100{ }^{\circ} \mathrm{C}$ in both situations, characterizing the loss of free and adsorbed water in the microparticles (SILVA et al., 2006; OLIVEIRA et al., 2014; XIAO et al., 2014; OLIVEIRA et al., 2018; SILVA et al., 2018). It is also possible to observe that there is a beginning of the polysaccharide degradation at about $200{ }^{\circ} \mathrm{C}$ (SILVA et al., 2018).

The maximum peak presented in both situations is attributed to the degradation of the polymeric network. Non-cross-linked samples presented lower degradation temperature $\left(312{ }^{\circ} \mathrm{C}\right)$ than the cross-linked samples $\left(316^{\circ} \mathrm{C}\right)$, reflecting about $70 \%$ of mass loss for both cases, indicating that the cross-linking process provided an increase in the material degradation temperature; and consequently, increased thermal stability. Similar results were reported by SILVA et al. (2018) by encapsulating dry green tea extract using cashew gum and maltodextrin as wall materials. The authors observed degradation stages around $300{ }^{\circ} \mathrm{C}$.

Thermogravimetric analysis (TGA) is used to investigate processes such as thermal stability and decomposition, dehydration, and oxidation (XIAO et al., 2014). The TGA measures changes in 


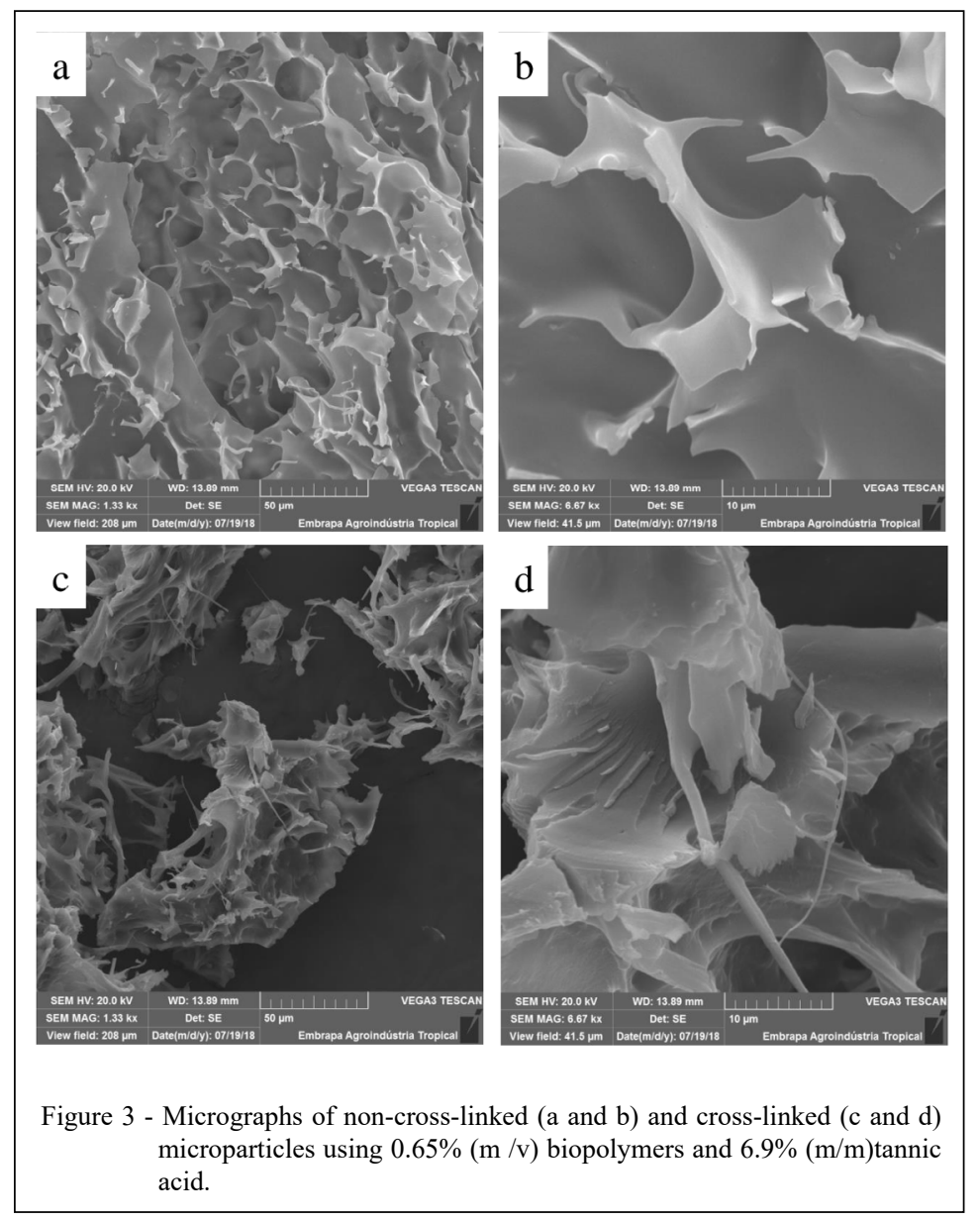

the mass of a sample as a function of temperature and time during heating (TENGKU-ROZAINA \& BIRCH, 2019). Moreover, this technique enables characterizing structural polymer modifications, thus being important to elucidate the effects of the cross-linking process on the thermal stability of the modified polysaccharide (SILVA et al., 2006).

\section{Infrared spectroscopic analysis}

The spectra of non-cross-linked and cross-linked microparticles are shown in Figure 5. The GE has amino groups in its composition, peaks in the region of $1420 \mathrm{~cm}^{-1}$ (XIAO et al., 2014) and bands at $1639 \mathrm{~cm}^{-1}$ and $1431 \mathrm{~cm}^{-1}$ from the amide carboxylate ion, observed in both microparticles (HAZIRAH et al., 2016; DUHORANIMANA et al., 2017; MUHOSA et al., 2019). The CG contains carboxyl groups, which corresponds to bands ranging around $2900 \mathrm{~cm}^{-1}$ (KOUPANTSIS et al., 2016; COMUNIAN et al., 2018). Other studies have also mentioned a broadband in the region of $3390 \mathrm{~cm}^{-1}$, being characteristic of the elongation of GE and $\mathrm{CG}$ O-H bonds (OLIVEIRA et al., 2014; PITOMBEIRA et al., 2015).

Chemical modification was confirmed by the absorption of intense peaks (Figure 5 GCGE-R) in the region between 1750 and $1000 \mathrm{~cm}^{-1}$, characterizing the vibrations of the carbonyl group of esters and aromatics, constituting groups which are present in tannic acid (KOUPANTSIS et al., 2016; PICCHIO et al., 2018).

\section{Toxicity test}

Rats showed no signs of acute toxicity. In addition, they responded satisfactorily to all stimuli and physiological needs, as there were no hair loss and no changes in their behavior.

Effects of cashew gum after ingestion are not known and it is important to evaluate the toxicological potential of the produced microparticles. The acute toxicity of cross-linked and non-cross-linked $\mathrm{CG} / \mathrm{GE}$ microparticles were 

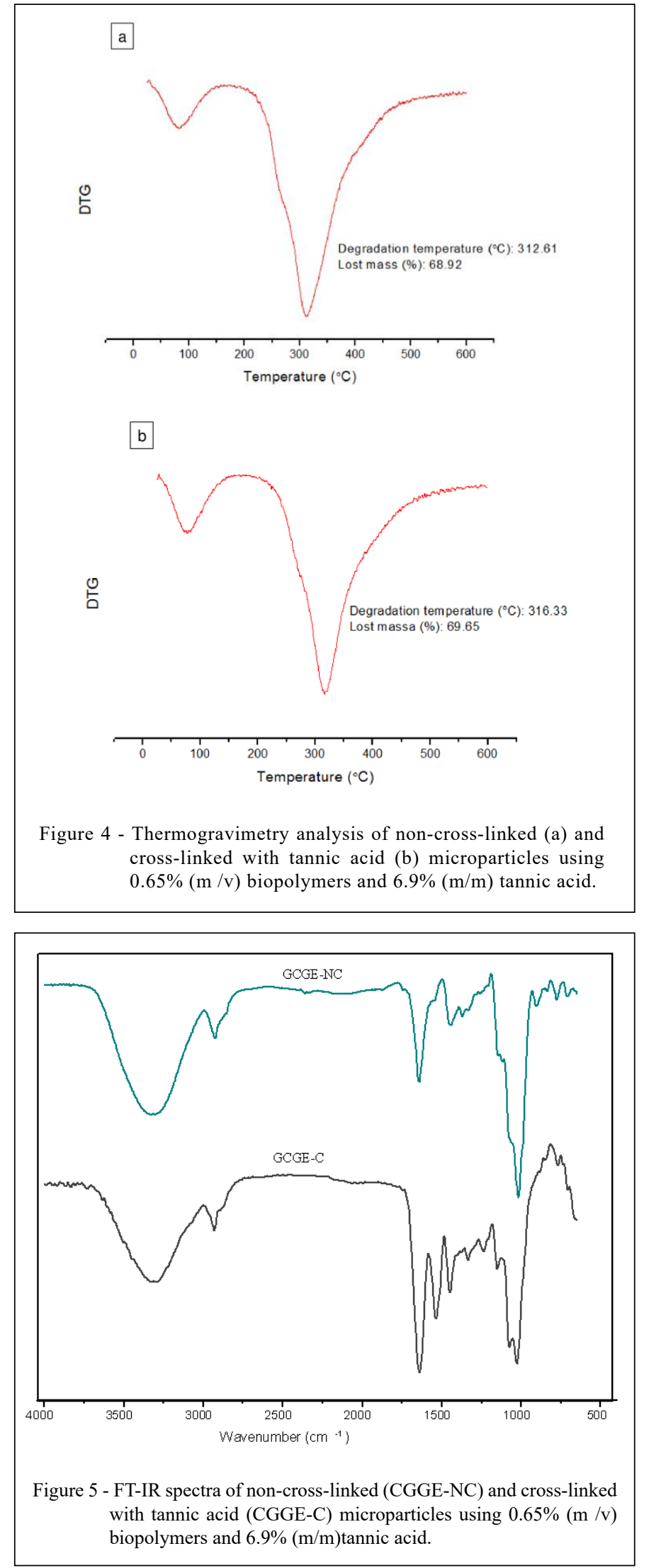

Ciência Rural, v.49, n.12, 2019. 
evaluated and the results obtained in this experiment showed no mortality at the evaluated dose. Thus, the microparticles are safe for oral use at a dose of 5000 $\mathrm{mg} / \mathrm{kg}$ body weight.

\section{CONCLUSION}

Increase of tannic acid in the crosslinked pequi oil particles resulted in higher yield and encapsulation efficiency, constituting important parameters for technological and industrial application. In addition, cross-linking provided an increase in material degradation temperature, increasing the thermal stability of the particles. Pequi oil particles have potential for use as an additive in cosmetic and food products or in the nutraceutical area.

\section{ACKNOWLEDGEMENTS}

The authors thank the Cearense Foundation for Supporting Scientific and Technological Development (FUNCAP) and the National Council for Scientific and Technological Development $(\mathrm{CNPq})$ for their scholarships. In addition, the authors thank the Brazilian Agricultural Research Corporation (Embrapa) for infrastructure and financial support.

\section{DECLARATION OF CONFLICT OF INTERESTS}

The authors declare no conflicts of interest. The founding sponsors had no role in defining the study; in the collection, analysis or interpretation of data; writing the manuscript; or deciding to publish the results.

\section{AUTHORS' CONTRIBUTIONS}

The authors contributed equally to the manuscript.

\section{REFERENCES}

ANVARI, M; CHUNG, D. Dynamic rheological and structural characterization of fish gelatin - Gum arabic coacervate gels cross-linked by tannic acid. Food Hydrocolloids, v.60, p.516-524, 2016. Available from: <https://doi.org/10.1016/j. foodhyd.2016.04.028>. Accessed: Nov. 10, 2018. doi: 10.1016/j. foodhyd.2016.04.028.

CANO-CHAUCA, M. et al. Effect of the carriers on the microstructure of mango powder obtained by spray drying and its functional characterization. Innovative Food Science and Emerging Technologies, v.6, p.420-428, 2005. Available from: $<$ https://doi.org/10.1016/j.ifset.2005.05.003>. Accessed: Oct. 20, 2018. doi: 10.1016/j.ifset.2005.05.003.

COMUNIAN, T. A. et al. Development of functional yogurt containing free and encapsulated echium oil, phytosterol and sinapic acid. Food Chemistry, v.237, p.948-956, 2017. Available from: $<$ https://doi.org/10.1016/j.foodchem.2017.06.071>. Accessed: Nov. 5, 2018. doi: 10.1016/j.foodchem.2017.06.071
COMUNIAN, T. A. et al. Effect of different polysaccharides and crosslinkers on echium oil microcapsules. Carbohydrate Polymers, v.150, p.319-329, 2016. Available from: <https://doi. org/10.1016/j.carbpol.2016.05.044> . Accessed: Nov. 5, 2018. doi: 10.1016/j.carbpol.2016.05.044.

COMUNIAN, T. A. et al. Enhancing stability of echium seed oil and beta-sitosterol by their coencapsulation by complex coacervation using different combinations of wall materials and crosslinkers, Food Chemistry, v.252, p.277-284, 2018. Available from: $<$ https://doi.org/10.1016/j.foodchem.2018.01.121>. Accessed: Nov. 5, 2018. doi: 10.1016/j.foodchem.2018.01.121.

DUHORANIMANA, E. et al. Effect of sodium carboxymethyl cellulose on complex coacervates formation with gelatin: Coacervates characterization, stabilization and formation mechanism. Food Hydrocolloids, v.69, p.111-120, 2017. Available: $<$ https://doi.org/10.1016/j.foodhyd.2017.01.035>. Accessed: May, 25, 2019. doi: 10.1016/j.fps1.2016.05.008.

FIGUEIREDO, P. R. L. et al. Caryocar coriaceum Wittm. (Pequi) fixed oil presents hypolipemic and anti-inflammatory effects in vivo and in vitro. Journal of Ethnopharmacology, v.191, p.87-94, 2016. Available from: $<$ https://doi.org/10.1016/j.jep.2016.06.038>. Accessed: Oct. 20, 2018. doi: 10.1016/j.jep.2016.06.038.

GEBBEN, B. et al. Intramolecular crosslink of poly (vinyl alcohol). Polymer, v.26, p.1737-1740, 1985. Available from: <https://doi. org/10.1016/0032-3861(85)90295-2>. Accessed: Jun. 5, 2018. doi: $10.1016 / 0032-3861(85) 90295-2$.

GOMEZ-ESTACA, J. et al. Encapsulation of an astaxanthincontaining lipid extract from shrimp waste by complex coacervation using a novel gelatin-cashew gum complex. Food Hydrocolloids, v61, p.155-162, 2016. Available from: <https://doi.org/10.1016/j. foodhyd.2016.05.005> Accessed: Oct. 20, 2018. doi: 10.1016/j. foodhyd.2016.05.005.

HAZIRAH, M. A. S. P. et al. Effect of xanthan gum on the physical and mechanical properties of gelatin-carboxymethyl cellulose film blends. Food Packaging and Shelf Life, v.9, p.55-63, 2016. Available from: <https://doi.org/10.1016/j.fpsl.2016.05.008>. Accessed: May, 25, 2019. doi: 10.1016/j.fpsl.2016.05.008.

HU, S. et al. Development of tannic acid cross-linked hollow zein nanoparticles as potential oral delivery vehicles for curcumin. Food Hydrocolloids, v.61, p.821-831, 2016. Available from: $<$ https://doi.org/10.1016/j.foodhyd.2016.07.006>. Accessed: Oct. 21, 2018. doi: 10.1016/j.foodhyd.2016.07.006.

HUANG, G. Q. et al. Complex coacervation of soybean protein isolate and chitosan. Food Chemistry, v.135, p.534539, 2012. Available from: <https://doi.org/10.1016/j. foodchem.2012.04.140>. Accessed: Oct. 21, 2018. doi: 10.1016/j. foodchem.2012.04.140.

KOUPANTSIS, T. et al. Glycerol and tannic acid as applied in the preparation of milk proteins - CMC complex coavervates for flavour encapsulation. Food Hydrocolloids, v.57, p.62-71, 2016. Available from: <https://doi.org/10.1016/j.foodhyd.2016.01.007>. Accessed: Oct. 21, 2018. doi: 10.1016/j.foodhyd.2016.01.007.

MA, T. et al. Effect of processing conditions on the morphology and oxidative stability of lipid microcapsules during complex coacervation. Food Hydrocolloids, v.87, p.637-643, 2019. Available from: <https://doi.org/10.1016/j. 
foodhyd.2018.08.053>. Accessed: Jan. 21, 2019. doi: 10.1016/j. foodhyd.2018.08.053.

MAGALHÃES, F. S. et al. Sequential process with bioadsorbents and microfiltration for clarification of pequi (Caryocar brasiliense Camb.) fruit extract. Food and Bioproducts Processing, v.108, p.105-116, 2018. Available from: <https://doi.org/10.1016/j.fbp.2018.02.003>. Accessed: Jan. 21, 2019. doi: 10.1016/j.fbp.2018.02.003.

MENEZES, M.L.L.R. et al. Effect of tannic acid as crosslinking agent on fish skin gelatin-silver nanocomposite film. Food Packaging and Shelf Life, v. 19, p. 7-15, 2019. Available from: $<$ https://doi.org/10.1016/j.fpsl.2018.11.005>. Accessed: Apr. 15, 2019. doi: $10.1016 /$ j.fpsl.2018.11.005.

MUHOSA, B. et al. Gelatin and pectin complex coacervates as carriers for cinnamaldehyde: Effect of pectin esterification degree on coacervate formation, and enhanced thermal stability. Food Hydrocolloids, v.87, p.712-722, 2019. Available from: $<$ https:// doi.org/10.1016/j.foodhyd.2018.08.051>. Accessed: May, 25, 2019. doi: 10.1016/j.foodhyd.2018.08.051.

NASCIMENTO, M. A et al. Micropartículas de Óleo de Pequi Obtidas por Coacervação Complexa com Goma de Cajueiro e Gelatina. Comunicado técnico, Embrapa. 2019. 7p. Available from: $<$ https://www.infoteca.cnptia.embrapa.br/infoteca/bitstream/ doc/1110768/1/COT19007.pdf>. Accessed: Oct. 14, 2019.

OLIVEIRA, E.F. et al. Alginate/cashew gum nanoparticles for essential oil encapsulation. Colloids and Surfaces B: Biointerfaces, v.113, p.146-151, 2014. Available from: $<$ https:// doi.org/10.1016/j.colsurfb.2013.08.038>. Accessed: Nov. 10, 2018. doi: 10.1016/j.colsurfb.2013.08.038.

OLIVEIRA, M. A. et al. Performance evaluation of cashew gum and gelatin blend for food packaging. Food Packaging and Shelf Life, v.17, p.57-64, 2018. Available from: <https://doi. org/10.1016/j.fpsl.2018.05.003>. Accessed: Nov. 15, 2018. doi: 10.1016/j.fpsl.2018.05.003

OLIVEIRA, M. L.M. et al.In vivo topical anti-inflammatory and wound healing activities of the fixed oil of Caryocar coriaceum Wittm. Seeds. Journal of Ethnopharmacology, v.129, p.214-219, 2010. Available from: <https://doi.org/10.1016/j.jep.2010.03.014> Accessed: Nov. 10, 2018. doi: 10.1016/j.jep.2010.03.014.

PICCHIO, M.L. et al. Casein films crosslinked by tannic acid for food packaging applications. Food Hydrocolloids, v.84, p.424-434, 2018. Available from: <https://doi.org/10.1016/j. foodhyd.2018.06.028>. Accessed: Nov. 10, 2018. doi: 10.1016/j. foodhyd.2018.06.028.

PINTO, M. R. M.R. et al. Encapsulation of carotenoid extracts from pequi (Caryocar brasiliense Camb) by emulsification $(\mathrm{O} / \mathrm{W})$ and foam-mat drying. Powder Technology, v.339, p.939-946, 2018. Available from: <https://doi.org/10.1016/j.powtec.2018.08.076>. Accessed: Nov. 10, 2018. doi: 10.1016/j.powtec.2018.08.076.

PITOMBEIRA, N.A.O. et al. Self-assembled nanoparticles of acetylated cashew gum: Characterization and evaluation as potential drug carrier. Carbohydrate Polymers. v.117, p.610-615, 2015. Available from: <https://doi.org/10.1016/j.carbpol.2014.09.087>. Accessed: May, 25, 2019. doi: 10.1016/j.carbpol.2014.09.087.

PRATA, A.S. et al. Release properties of chemical and enzymatic crosslinked gelatin-gum Arabic microparticles containing a fluorescent probe plus vetiver essential oil. Colloids and Surfaces B: Biointerfaces, v.67, p.171-178, 2008. Available from: $<$ https:// doi.org/10.1016/j.colsurfb.2008.08.014>. Accessed: May, 22, 2019. doi: 10.1016/j.colsurfb.2008.08.014

QUIRINO, G. S. et al. Healing potential of Pequi (Caryocar coriaceum Wittm.) fruit pulp oil. Phytochemistry Letters, v.2, p.179-183, 2009. Available from: <https://doi.org/10.1016/j. phytol.2009.06.002>. Accessed: Nov. 10, 2018. doi: 10.1016/j. phytol.2009.06.002.

RIBEIRO, F. W. M. et al. Chemical modification of Gum Arabic and Its Application in the encapsulation of Cymbopogon citratus Essential Oil. Journal of Applied Polymer Science, v.132, p.17, 2015. Available from: <https://doi.org/10.1002/app.41519>. Accessed: May, 10, 2019. doi: 10.1002/app.41519.

ROCHA-SELMI, G. A. et al. Double emulsion stage prior to complex coacervation process for microencapsulation of sweetener sucralose. Journal of Food Engineering, v.119, p.28-32, 2013. Available from: $<$ https://doi.org/10.1016/j.jfoodeng.2013.05.002>. Accessed: May, 22, 2019. doi: 10.1016/j.jfoodeng.2013.05.002.

ROY, J. C. et al. Influence of process parameters on microcapsule formation from chitosan-Type B gelatin complex coacervates. Carbohydrate Polymers, v.198, p.281-293, 2018. Available from: $<$ https://doi.org/10.1016/j.carbpol.2018.06.087>. Accessed: Nov. 10, 2018. doi: 10.1016/j.carbpol.2018.06.087.

SANTOS, T. M. et al. Enhancing storage stability of guava with tannic acid-crosslinked zein coatings. Food Chemistry, v.257, p.252-258, 2018. Available from: < https://doi.org/10.1016/j. foodchem.2018.03.021>. Accessed: Aug. 05, 2019. doi: 10.1016/j. foodchem.2018.03.021.

SHADDEL, R. et al. Double emulsion followed by complex coacervation as a promising method for protection of black raspberry anthocyanins. Food Hydrocolloids, v.77, p.804-816, 2018. Available from: $<$ https://doi.org/10.1016/j.foodhyd.2017.11.024>. Accessed: Nov. 10, 2018. doi: 10.1016/j.foodhyd.2017.11.024.

SILVA, D. A. et al. Characterization of crosslinked cashew gum derivatives. Carbohydrate Polymers, v.66, p.16-26, 2006. Available from: <https://doi.org/10.1016/j.carbpol.2006.02.021>. Accessed: May, 22, 2019. doi: 10.1016/j.carbpol.2006.02.021.

SILVA, F. et al. Cashew gum and maltrodextrin particles for green tea (Camellia sinensis var Assamica) extract encapsulation. Food Chemistry, v.261, p.169-175, 2018. Available from: $<$ https://doi-org.ez11.periodicos.capes.gov.br/10.1016/j. foodchem.2018.04.028>. Accessed: May, 22, 2019. doi: 10.1016/j. foodchem.2018.04.028

SILVA, L.C. et al. Optimization of cashew gum and chitosan for microencapsulation of pequi oil by complex coacervation. Journal of Food Processing and Preservation, v.42, p.1-8, 2017. Available from: <https://doi.org/10.1111/jfpp.13538>. Accessed: May, 22, 2019. doi: 10.1111/jfpp.13538.

SIOW, L. F.; ONG, C. S. Effect of pH on Garlic Oil Encapsulation by Complex Coacervation. Journal Food Processing Technology, v.4,p.1-5, 2013. Available from: <https://dx.doi.org/10.4172/2157-7110.1000199>. Accessed: May, 22, 2019. doi: 10.4172/2157-7110.1000199.

TENGKU-ROZAINA, T.M.; BIRCH, E.J.; Thermal Analysis for Lipid Decomposition by DSC and TGA. Encyclopedia of food

Ciência Rural, v.49, n.12, 2019. 
chemistry, v.2, p.345-352, 2019. Available from: <https://doiorg.ez11.periodicos.capes.gov.br/10.1016/B978-0-08-1005965.21674-0>. Accessed: Nov. 14, 2018. doi: 10.1016/B978-0-08100596-5.21674-0.

TIMILSENA, Y. P. et al. Advances in microencapsulation of polyunsaturated fatty acids (PIFAs)-rich plant oils using compex coacervation: A review. Food Hydrocolloids, v.69, p.369-381, 2017. Available from: <https://doi.org/10.1016/j. foodhyd.2017.03.007>. Accessed: Dec. 14, 2018. doi: 10.1016/j. foodhyd.2017.03.007.

TIMILSENA, Y. P. et al. Microencapsulation of chia seed oil using chia seed protein isolate-chia seed gum complex coacervates. International Journal of Biological Macromolecules, v.91, p.347-357, 2016. Available: <https://doi.org/10.1016/j. ijbiomac.2016.05.058>. Accessed: Nov. 14, 2018. doi: 10.1016/j. ijbiomac.2016.05.058.

TORQUATO, D. S. et al. Evaluation of antimicrobial activity of cashew tree gum. World. Journal of Microbiology and Biotechnology, v.20, p.505-507, 2004. Available from: <10.1023/B: WIBI.0000040407.90110.c5>. Accessed: Jul. 15, 2018. doi: 10.1023 / B: WIBI.0000040407.90110.c5.
WANG, B. et al. Optimization of the microencapsulation of tuna oil in gelatin-sodium hexametaphosphate using complex coacervation. Food Chemistry, v.158, p.358-365, 2014. Available from: $<$ https://doi.org/10.1016/j.foodchem.2014.02.135>. Accessed: Jul. 14, 2018. doi: 10.1016/j.foodchem.2014.02.135.

XIAO, Z. et al. Production and characterization of multinuclear microcapsules encapsulating lavender oil by complex coacervation. Flavor and Fragrance Journal, v.29, p.166-172, 2014. Available from: <https://doi.org/10.1002/ffj.3192>. Accessed: Jul. 14, 2018. doi: $10.1002 / \mathrm{ffj} .3192$.

XU, J.B. et al. Preparation and characterization of alginate-carrageenan hydrogel films crosslinked using a water-soluble carbodiimide (WSC). Journal of Membrane Science, v.218, p.131-146, 2003. Available from: <https://doi-org/10.1016/S0376-7388(03)00165-0>. Accessed: Jul. 10, 2018. doi: 10.1016/S0376-7388(03)00165-0.

ZHANG, Z. Q. et al. Tannic acid cross-linked gelatin-gum Arabic coacervate microspheres for sustained release of allyl isothiocyanate: Characterization and in vitro release study. Food Research International, v.44, p.1000-1007, 2011 Available: $\quad<$ https://doi-org/10.1016/j.foodres.2011.02.044>. Accessed: Jan. 15, 2019. doi: 10.1016/j.foodres.2011.02.044 